\title{
A Collective Consideration of the EU's Capital Market Legislation
}

\author{
John A. Consiglio ${ }^{1}$ \\ ${ }^{1}$ Department of Banking \& Finance, The University of Malta, Malta \\ Correspondence: John A. Consiglio, Ph.D., Senior Lecturer, Department of Banking \& Finance, The University of \\ Malta, Malta.
}

Received: October 19, 2015

Accepted: November 18, 2015

Online Published: December 28, 2015

doi:10.5430/ijfr.v7n1p 86

URL: http://dx.doi.org/10.5430/ijfr.v7n1p86

\begin{abstract}
As the European Union EU) adjusts itself to its early years after creation of its Banking Union, the financial market discourse increasingly points towards the necessity of an enhanced competitiveness that, it is often held, cannot do without a complementing Capital Markets Union (CMU). This paper considers some of the leading legislative efforts which, going back to the early years of this century, have in fact been key underpinnings of whatever format the CMU may eventually take. It also views such legislation within a general context of better regulation.
\end{abstract}

Keywords: capital markets, EU financial legislation, regulation

\section{Introduction}

The main details of the European Union's thinking on the building of a Capital Markets Union in the eurozone were presented by the European Commission in, firstly, a 2015 Working Document (SWD, 2015, 183 final), with then in the same year subsequent Action Plan details in another two documents, viz CMU (2015) 468 final, and SWD (2015) 184 final. These are frameworks that explore, inter alia, the inherent importance of such a CMU, the absolutely necessary taking stock of what and where stand (i.e. current financing models) the present European capital markets, the issue of new needed financing instruments, and cross border financing issues.

But this current "rediscovery" of realities in the Union's capital markets is not at all totally without precedent. Even if it is a discourse that gains momentum as we write, it must be considered against the background of the many EU measures which, many dating towards the turn of this century, have been enacted and implemented on issues dealing with capital. This paper presents a brief panoramic walk-through of a number of issues that characterise capital market legislation in the European Union (EU). This is an area that has seen rapid development over recent years, but such development has probably waylaid what was initially politically desired to be a much more coherent structuring process, similar perhaps in terms of success to others in the building of the Union (e.g. EMU), That this has not as yet realistically come about is a multifacted issue, and what we actually attempt here are essentially very generic considerations that in reality merit much lengthier treatment.

In its 3rd May 2005 Green Paper on Financial Services Policy, for the then envisaged period of 2005 through 2010 (notice, quite ahead of 15th September 2008 and Lehmann Brothers), the European Commission (EC) had recommended for future legislation by the European Parliament (EP) an attempt at "better regulation". It was then the Commission's opinion that the whole process of law making and application had to be transparent (Note 1), based on impact assessment aimed at showing the economic benefits of proposed measures, and legislating procedure was envisaged to thenceforth take place with the participation of all affected groups.

In the White Paper published a few months later the Commission picked up on these concepts and underlined the fact that in the future it would act in accordance with the principle of, again, "better regulation". An important component of better regulation was this time round clearly stated to be a continuous assessment and evaluation of all new legislative measures. This then envisaged continuality characteristic must however be critically placed against the backdrop of the fact that the Commission did not in fact at that time plan any new legal actions or procedures affecting such (later to be seen as vital!) areas as rating agencies, the operating methods and approaches of financial analysts or intermediaries of various types, measures regarding offer documents in takeover bids, and, by no means least important, that of capital requirements for operators in certain regulated financiasl markets. 


\section{Post Lehmann and Regulation}

Was the onset of Lehmann in 2008 the basic raison d'etre for the February 2009 de Larosiere Report? (Note 2) Very soon afterwards the financial crisis imposed totally different approaches to what shape "better regulation" would have to take. Some seven months after de Laroisiere the Commission communicated a comprehensive package of legislative measures in the direction of pan-EU supervision of financial service providers, capital markets activity (micro-prudential suopervision) and, eventually, the European System of Financial Supervisors (ESFS) whose building blocks were established in 2010. (Note 3)

As the crisis intensified there was never any dearth of nodal operational areas at which public, media, and political pressure was not targeted. Capital adequacy of all institutions in all the three main financial services sectors (banking, insurance, sexcurities and investments markets), adequacy of on-site supervising, the size of bankers' remuneration packages, tav evasion and havens, governance practices, political goodwill, the austerity versus economic growth conundrum, and the role of rating agencies, these and others were, and still are, constantly on EU citizens' minds.

\section{Rating Agencies}

On rating agencies particularly, the misguided popular stance often looks like a submissive notion that there is, with regards to these institutions no answer to the old question of qui custodet ipsos custodes, who will now be controlling/rating the raters? But that is not fact. The EC first addressed the issue of rating agencies in April 2002. From then on an interesting metamorphosis seems to be evolving. First, in April 2006, the Commission reached a conclusion that no legislative initiatives were needed. (Note 4) Then, when the crisis broke out, the popular realisation was that credit agencies were partly to blame for incorrect evaluation of credit risks.

An initial answer to this came on the 16th September 2009 when the European Parliament (EP) and the Council submitted the agencies to a new Regulation. (Note 5) The inspiring thinking was that if these agencies would follow the principles as outlined in the Recital to this new Regulation, (Note 6) then all ratings would be independent, objective, and of adequate quality. Supervision of agencies had therefore then theoretically come into the EU's armoury. But that was either not sufficiently communicated to the institution's customers or ineffectively put into practice. The crisis persisted, and in June 2010, when the EC presented amendments to the original Regulation, this time it very much seemed as if another regulatory body seemed to have got its teeth into the agencies problem. The first time round it had been IOSCO, this time it was the ESMA who would become the focal regulatory point for the agencies. The Commission's amending Proposal was adopted on the 15th December 2010, with then a further amendment to the same Regulation coming again in November 2011, introducing civil liability for incorrect credit ratings and stricter disclosue obligations for the agencies.

In all of this the European Union seemed to be very much behind what had been happening at the other end of the world. In Australia for example the Australian Securities and Investments Commission on the 12th November 2009 had introduced changes (effective from 1 Jan 2010) to the regulation of what the credit rating agencies could do in that continent. A system of licensing was introduced setting outr wide ranging obligations in areas such as avoidance of conflict of interest, having adequate resources (financial, human, and IT) available, having properly trained and competent analysts, having risk management systems in place, and proper provision of the rating service itself. Before long the full might of these regulations was felt there in a number of court cases that earned victims reparatory damages.

\section{Single Market Efficiency}

A position that all of the above problems awkwardly came to the fore at a time when the inherent objective of most of EU legislature was focussed elsewhere, is not incorrect. In the field of capital markets, the EU's legislative objective was that, going as far back as 1987's Single European Act (SEA), of achieving a single European market for financial services, one that would ensure capital market efficiency and investor protection. Bumke (2005) criticises the securities markets as falling short of ensuring institutional, operational, and allocational afficiency. Franke and Hax (2009) also go into the question of at what cost to the issuer these efficiencies can be brought about.

Capital market regulation requires two fundamental approaches, viz transparency, and a system of enforcement. Whilst transparency is considered as the central element (vide Avgouleas 2005), enforcement is often misinterpreted in that its possible multilateral components, viz private self-monitoring, private external monitoring, and administrative supervision, are not only often missed but, in the context of the EU's legislative actiivities, each display strong differences. The private self-monitoring carried out by investment firms and intermediaries (investment firms, financial analysts, and rating agencies) consists mainly of provisions on company organisation 
and prevention of conflict of interests. European rules on corporate and accounting law clearly define experts' and auditors' monitoring. And administrative supervision mostly remains a matter for the member states.

Most of the EU's capital market directives have an underpinning genus in the European legislature's competence to ensure the freedom of establishment by coordinating national provisions on the protection of creditors, shareholders, and investors. This competence's development iter goes via, first, Article 54(3)(g) of the EEC Treaty (1957), then Article 44(2)(g) in the Treaty of Amsterdam (1995), and now the similar Article 50(2)(g) in the Treaty on the Functioning of the European Union (TFEU) (2009). But again the criticism made through these stages (e.g. Bleckmann (1992), Kindler (1994), Muller-Graff (2010)) often was that the provision only allows a coordination of national rules, i.e. an approximation of national laws, as opposed to a full unification. (Note 7)

\section{Definitional Problem}

Veil (2013) interestingly holds that no generally accepted definition of capital market regulation exists as yet. Clearly any potential attempt at one would need to define both regulation itself and capital markets, as well as tackling the two issues of market regulation versus market supervision, and capital markets versus general financial markets regulation. The latter is a far wider scenario, in that it covers all activities in the areas of securities trading, banking, and insurance markets. It is also commonly held to be structured into prudential regulation and conduct of business regulation.

Within the European Union national cultures still provide some support to the theory that financial regulation is one form of social activity whose form is influenced by time and place. Cultural theories of regulation (Note 8) try to link change and breakdown generally with contemporary changes and breakdowns within cultures of market capitalism. In terms of regulatory "style" Kelmen S. (1983) and Vogel D (1983) for example consider US regulation as being based on a search for precise standards and generally adversarial, reflecting historical antagonism between the business community and the state. In Britain on the other hand regulation is often seen as tending to be cooperative, voluntary, based on trust, and allowing discretion to both regulator and regulatee, reflecting a "weak state" tradition, and a less aggressive appetite for competition by British capitalists. (Note 9) The whole apparent preference for so-called "self-regulation", which over time has often been seen to have failed, is perhaps another indication of this. (Note 10)

The autonomous national rules implemented by many EU member- states often exceed provisions of European law. Minimum harmonisation allows for such "gold- plating", but then may simultaneously be considered as inimical towards ful EU law harmonisation itself. Even as the UK moved from the former Financial Services Authority (FSA) to its successor, the Financial Conduct Authority (FCA), the tendency towards preference for the "principles-based" model of regulation remained still in effect, this actually being a second level of regulation next to implemented European directives. This could be considered as a situation where use is made of abstract standards and objectives, rather than application of detailed, prescriptive rules. Principles only define regulatory objectives, leaving market participants to find more effective ways of achieving what could even be popularly considered as nationally desired outcomes. (Note 11)

\section{Other Problem Areas}

European capital markets legislation has now developed a complicated dynamic. Those who wish to be positive about this may consider it as supporting the belief that it is now increasingly providing protection against weak systems of governance (e.g. in banks) which increase the liklihood of financial fraud or loss. But it is also, factually, a complicated dynamic. And this of course stems from the simple truth of so many areas and aspects which such legislation is continuously called to deal with. In this paper space forces us to inevitably miss several, and a mere citation of some of them may help redress this. Consider, for example, issues like:

\subsection{Regulation of Short Selling, and of Certain Aspects of Credit Swaps}

After November 2012 the EU's Regulation No. 236/2012 started to go into the areas of definition, calculation of net short positions, covered sovereign credit default swaps, notification tresholds, liquidity tresholds for suspending restrictions, significant falls in the values of financial instruments, and adverse events. But, right across the EU, positions in this area differed drastically.

A group of nine member-states considered the Regulation's provisions on market abuse as sufficient. Others, like Denmark, differed outrightly and prohibited naked short sales entirely. Yet another group (seven states) combined disclosure obligations for short sales and prohibitions of naked short selling. And Luxembourg and the UK also engaged in further other finer differences to practice. As at June 2013 ten investment firms and asset managers held 
28 per cent of all significant short-selling poasitions in the EU, according to statistics compiled under the 27-nation bloc's above quoted regulation. (Note 12)

\subsection{Takeover Bids}

EU company and capital markets law in this area lies mainly in the Takeover Directive 2004/25/EC, but not only is this a case where implementing measures are very short on the ground, but the EU's institutions (EP, Council, ECOSOC, and Commission of the Regions) still seem to be labouring on a Staff Working Document (21.2.2007, SEC (2007) 268) about its complete acceptance and application in all member-states.

\subsection{Undertakings for Collective Investments in Transferable Secuirities (UCITS)}

This is a fast growing and immensely important area in EU investment markets. It is mostly governed by no less than three EU Directives and a Regulation, (Note 13) and insofar as their impact is concerned, even in small develooping markets (e.g. Malta and Cyprus), the specialisation has been the subject of various research efforts.

\subsection{Integrated Supervision}

Sweden and Denmark were amongst the earlier EU states to participate in integrated supervision of securities trading. The next step then was single supervisory authorities for all the financial service markets (e.g. the UK's FSA in 1997; Germany's move in 2002 from the former BAWe (for securities), BAKred (for banking), and BAV (for insurances), into a BaFIN as required by the Integrated Financial Supervision Act BGB1 (2002); Austria in 2002; then in Belgium and Finland; and later in the group of ten states that joined the EU in 2004. But is the model now on a reverse route? The UK has now effectively given up the single regulator structure, and the situation there is essentially that of two regulatory institutions, viz the old Bank of Ebngland and the Prudential Regulation Authority (PRA).

\section{Market Abuse}

There was a time when just the term "insider trading" seemed, in perhaps a low key, to popularly encapsulate all that was not acceptable and forbidden in capital markets. One would be justified in recognising how far ahead the US was to the EU in this area, they having already had on their statute books a law in this area in 1934. (Note 14) In Europe it was around the 1980s that some states introduced their first provisions in this area. Now most hope lies in the Market Abuse Directives Nos. 2003/124/EC and 2004/72/EC and various other, thence inspired, national states' similar laws. These however can be substantially different in their implimentation provisions amongst the various states, e.g. in the area of imposition of criminal sanctions.

\section{Conclusion}

The above areas (others could no doubt be added, e.g. the Prospectus Directive, and the Transparency Directive), and our preceding introductory considerations, can all potentially contribute to a "where's the rainbow's end, and where's the gold pot?" stance in the disheartened, who are often seeking clarity, or conformity, or even simple unity, in European capital markets law.

Cumulatively this discipline - often too simply (and incorrectly) presented as just Financial Services Regulation increasingly suggests it is still way off from what many, undoubtedly misguidedly, consider it should be contributing towards, by way of definitive solutions, or even outright total elimination of all sorts of financial crises. But then the truth of course is that general economic conjunctures and policies have just as important or prominent a role as the discipline itself undoubtedly has - whether it is dubbed as law, or soft law, or indeed even regulation (under either the current "prudence" or "business conduct" tags)., In simple terms it is all "law" but at the same time it is also all always economic conjunctures, and these change continuously.

\section{References}

Bumke, C., Hopt, K. J., \& et al. (2005). Kapitalmarktgesetzgebung in europaischen Binnenmarkt.

Cf Bank of England/FSA. (2011). The Bank of England, Prudential Regulation Authority - Our Approach to Banking Supervision.

Commission Proposal for a Regulation of the EP and of the Council amending Regulation (EC) No. 1060/2009 on credit rating agencies. COM (2011) 742/2.

Franke, G., \& Hax, H. (2009). Finanzewirtschaft des Unternehmens und Kapitalmarkt, p.56.

Green Paper on Financial Services Policy. (2005-2010). 3 May 2005, COM (2005) 177 final. 
Kelmen, S. (1983). Regulating America, Regulating Sweden - A Comparative Study of OHS. Cambridge, Mass, MIT Press.

Macneil, I., \& O'Brien, J. (eds). (2005). The Future of Financial Regulation. Hart Publishing Ltd, Oxford and London, p 205, 209.

Veil, R. (2013). European Capital Markets Law. Hart Publishing, p 27.

Vide e.g. Gribbon, G. (2012). UCITS and the Maltese Funds Industry. Unpublished thesis B.Comm (Hons) Banking \& Finance in the Department of Banking \& Finance, The University of Malta.

Vogel, D. (1978). Why Businessmen distrust their state. The Political Consciousness of American Corporate Executives. British Journal of Political Science, 8, 45-78.

White Paper on Financial Services Policy. (2005-2010). 1 December 2005, COM(2005) 629 final, p.5 ff.

\section{Notes}

Note 1. The concept of Better Regulation is however formally described as actually also having to satisfy the principles of necessity, proportionality, sunsidiarity, accountability, accessibility, and simplicity.

Note 2. The report - The High-Level Group on Financial Supervision in the EU-was published on the $29^{\text {th }}$ Fenruary 2009 and had almost 100 pages of recommendations on global financial stability, uniform supervisory standards, and the guaranteeing of cooperation between national supervisory authorities.

Note 3. Some observers have drawn an analogy between the European Central bank's ESCB (European System of Central Banks) for centralized monetary policy control, with this ESFS which eventually came to today's European Banking Union with a structure comprising the European Banking Authority (EBA), the European Insurance and Occupational Pensions Authority (EIOPA), and the European Securities Markets Authority (ESMA).

Note 4. Cf. Communication from the Commission on Credit Rating Agencies, 11 March 2006 (2006/C 59/02. IOSCO had apparently managed to get the Commission's support to its view that self-regulation would be sufficient if properly done by the agencies themselves.

Note 5. Regulatiopn (EC) No. 1060/2009 of the European Parliament and of the Council of $16^{\text {th }}$ September 2009 on Credit Rating Agencies, OJ L302, 17 November 2009.

Note 6. Viz integrity, transparency, responsibility, and good governance. Vide Recital 1 to Reg. (EC) 1060/2009 op cit.

Note 7. Cf Bleckmann A., ZGR Journal (1992), p 364, 372-373; Kindler P. (1994), ZHR Journal, p 339, 352; Muller-Graff P.C. in R. Streinz (ed) (2003), Vertrag uber die Europanische Union und Vertrag zur Grundung der Europeaischen Gemeinschafty - Kommentar, para 17.

Note 8. Considered here in the framework of Moran M.'s seminal structurisation of financial market regulation, viz public-interest theories, instrumental theories, cultural theories, and administrative theories.

Note 9. Kelmen S. (1983) - Regulating America, Regulating Sweden - A Comparative Study of OHS - Cambridge, Mass, MIT Press, and Vogel D. (1978) - Why Businessmen distrust their state. The Political Consciousness of American Corporate Executives - British Journal of Political Science, Vol 8, pp 45-78.

Note 10. Several EU states complement public regulation by a more or less developed self-regulation which, however, mainly concerns the dealing on the unregulated markets not covere by EU legislation, e.g. Germany's Freiverkehr (Open Market), or the UK's Alternative Investment Market (AIM). These markets are usually subject to their local stock exchanges and their listing rules.

Note 11. Sometheorists have also seen in this yet another example of the E.J. Kane model of continuous re-regulation, inspired at its source by the Hegelian dialectic model.

Note 12. From statistics compiled by the European Securities and Markets Authority (ESMA) - Financial Times, June 3, 2013.

Note 13. Viz Council Directive 85/611/EEC of $20^{\text {th }}$ December 1985; Commission Directive 2007/16/EC of $19^{\text {th }}$ March 2007; Directive 2002/65/EC of the EP and of the Council of $23^{\text {rd }}$ September 2002; and Regulation (EC) No. 1606/2002 of the EP and of the Council of $19^{\text {th }}$ July 2002.

Note 14. In 1934 the federal legislature passed the Securities Exchange Act, and the Securities and Exchange Commission prescribed the new SEC Rules. 